\title{
A LITERATURA BÍBLICA E A RESTRIÇÃO DE DIREITOS ÀS MULHERES NA HISTÓRIA DO DIREITO OCIDENTAL
}

\author{
Athena de Oliveira Nogueira Bastos ${ }^{1}$ \\ Luiz CARlos CANCELlier de OLIVO
}

\begin{abstract}
RESUMO: O direito ocidental contemporâneo encontra origem intrinsecamente interligada ao direito divino, baseado na mensagem transmitida pela Bíblia. Considerada enquanto conjunto de livros, observa-se que a Bíblia não somente foi objeto das escolhas literárias dos indivíduos que a compuseram e editaram, como pretendeu transmitir suas intenções. Desse modo, a ela podem ser aplicadas regras de interpretação literária, que possibilitam uma compreensão mais apurada da sua mensagem e de que como esta foi moldada pelas escolhas a ela aplicadas. $\mathrm{O}$ objetivo deste trabalho, portanto, é analisar de que forma a literatura bíblica foi constituída e alterada, de modo a compreender como a figura feminina foi representada e quais as consequências da sua representação literária nos direitos das mulheres dentro da instituição religiosa. Ainda, visto que a religião foi importante fator na definição da moral e do direito ocidental, pretende observar qual o reflexo, na sociedade, das alterações em passagens bíblicas que discorram sobre os direitos das mulheres, considerandose segundo o ideal de dignidade e igualdade transmitido pelos pregadores cristãos e que hoje norteiam a majoritária parcela dos ordenamentos jurídicos ocidentais.
\end{abstract}

Palavras-Chave: história do direito; literatura bíblica; cristianismo primitivo; direitos das mulheres.

1 Graduada em Direito pela Universidade Federal de Santa Catarina (UFSC). Mestranda do Programa de Pós-Graduação em Direito da Universidade Federal de Santa Catarina (UFSC), na área de Teoria e História do Direito e na linha de pesquisa Conhecimento Crítico, Historicidade, Subjetividade e Multiculturalismo. Bolsista do CNPq. Florianópolis, SC, Brasil. CV Lattes: http://lattes.cnpq.br/6946288553792220. E-mail: athena.bastos@hotmail.com.

2 Doutor em Direito pela Universidade Federal de Santa Catarina (UFSC). Graduado e Mestre em Direito Universidade Federal de Santa Catarina (UFSC). Líder do Grupo de Pesquisa Direito e Literatura (CNPq). Florianópolis, SC, Brasil. CV Lattes: http://lattes.cnpq.br/5439364689304327. E-mail: cancellier@uol.com.br. 


\section{INTRODUÇÃO}

Estudar a história do direito ocidental exige uma passagem pelo estudo da conexão entre direito e religião, dado que a atuação da Igreja Cristã Católica foi - e ainda é - parte essencial da definição de condutas sociais moral e legalmente autorizadas. Por um vasto período, o direito divino conduziu o direito dos homens. E, por sua vez, o direito divino era orientado pela mensagem contida em um conjunto de livros escritos, editados e reorganizados desde o primeiro milênio anterior à era cristã, detentor da "verdade" que alguns grupos desejaram transmitir às gerações futuras.

A Bíblia, enquanto conjunto de textos em que elementos figurativos são empregados com o objetivo de transmitir e registrar ideias, consiste em literatura e, como tal, pode ser analisada conforme as regras de interpretações comumente aplicadas aos estilos literários ${ }^{3}$. Ademais, é preciso considerar que nela encontramos gêneros diversos - narrativa, carta, poesia, parábola, entre outros -, variada tipologia textual - como, por exemplo, descrição, narração, argumentação e predição, na qual se sustentam os oráculos, vaticínios e profecias- e o uso de diferentes figuras de linguagem - comparação, metáfora, alegoria etc. À análise de tais aspectos, que se insere no campo dos estudos linguísticos, sofre limitações uma vez que se trata de uma obra que não pode ser dissociada de tamanha crença e discussão transcendental, como destacam os autores Gabel e Wheeler (2003, p. 17) e Zabatiero e Leonel (2011, p. 19 ).

De igual modo, por muito tempo a visão da Bíblia como literatura enfrentou como obstáculo, de um lado, a vertente que alegava a sacralidade do texto como impedimento para a sua consideração literária e, de outro, a vertente que afirmava a oposição entre a visão literária e visão críticohistórica do conjunto, dada a sua influência contextual. Esta última considerava o fato de que a pesquisa linguística da Bíblia concentrou-se, inicialmente, em uma negação do conteúdo em função da forma. Todavia, como dissertam Zabatiero e Leonel (2011, p. 19-28), não se trata de negar as abordagens de paradigma histórico e filosófico, mas de propor uma nova visão de pesquisa que considere também o interesse literário.

3 Para as várias formas de interpretar a Bíblia como literatura, ver Zabatiero e Leonel (2011). 
O estudo literário da Bíblia não pressupõe necessariamente o questionamento da crença que ela transmite, tampouco pretende ignorar o caráter histórico adquirido pelas palavras, mas visa a explicar as motivações por trás delas e qualificar as interpretações que delas se podem extrair.

Considerando a influência que este livro exerceu no direito ocidental, é de suma importância que esse estudo seja realizado. Compreender o cânone cristão como fruto da escolha de indivíduos de épocas e locais distintos, com visões e interesses diferentes, pode explicar inúmeros problemas interpretativos da modernidade. Mais do que isso, pode contribuir para a superação de conflitos atuais e para o avanço do direito moderno, enquanto embasado no princípio da igualdade e da dignidade humana, ideias já expressas na literatura cristã.

No tocante às divergências relacionadas aos direitos de gênero, por exemplo, é imprescindível observar qual a mensagem que se pretendeu passar com o cânone acerca das mulheres e as justificativas para as modificações estabelecidas literariamente, as quais tiveram consequências práticas em seus direitos. Embora os direitos de gênero tenham progredido nas últimas décadas e o princípio da igualdade seja fundamental perante a Carta Maior, a diferenciação ainda é existente e encontra razão na moralidade constante na Bíblia.

Ainda que o cânone apresente uma proposta de igualdade e dignidade às mulheres, a qual foi essencial para a aquisição de determinados direitos na sociedade berço do cristianismo, seus textos foram objeto de modificações que visaram a delimitar o papel da mulher dentro da instituição religiosa e a apagar sua participação na consolidação dela, a exemplo das falsificações presentes nas cartas paulinas.

Não se pretende adentrar no mérito sobre a veracidade dos fatos narrados nos textos bíblicos que foram tornados canônicos, mas identificar a forma como tal literatura influenciou na concepção do papel e dos direitos femininos segundo o pensamento ocidental. Portanto, o objetivo deste trabalho não é examinar a existência das personagens bíblicas femininas ou aprofundar a discussão da autenticidade dos textos. Trata-se de analisar qualitativamente os aspectos da sua representação no processo de construção do cânone - escrita, seleção de textos, edição, falsificação - por 
meio de uma abordagem histórica da relação entre direito e religião e do estudo de métodos de interpretação literária da Bíblia.

Pretende-se, desse modo, partir da discussão acerca das intenções intrínsecas à construção do cânone bíblico, conectando-as com as modificações propostas no tocante aos indivíduos do sexo feminino conforme a posição sociopolítica por eles ocupados. Então, poder-se-á responder, através de método dedutivo, se as escolhas da Igreja primitiva ${ }^{4}$ relativas à construção do cânone convergiram para a restrição dos direitos das mulheres.

\section{A CONSTRUÇÃO DO CÂNONE E SUAS INTENÇÕES}

A construção de um cânon ${ }^{5}$ da literatura bíblica foi uma importante ferramenta de consolidação do cristianismo. A seleção de livros oficiais entre tantos registros - embasados, sobretudo, em fontes orais - garantiu que as discussões em torno de diferentes interpretações não impedissem a expansão da religião em seus primeiros séculos, bem como atuou na homogeneização da crença e das práticas cristãs no vasto Império Romano. Questiona-se, porém, de que modo a seleção ocorreu e quais foram os critérios utilizados. O que motivou a escolha de determinados livros em detrimento de outros?

Em primeiro lugar, é imprescindível situar a Bíblica no campo da literatura. Zabatiero e Leonel (2011), da mesma forma que Gabel e Wheeler (2003), explicitam, em suas obras, os elementos que permitem a análise dos textos canônicos sob a perspectiva literária. A literatura, destaca-se, constitui uma relação com a realidade através de propriedades de linguagem, de forma que se estabelecem duas proposições. A primeira proposição, referente à relação social, remete aos conceitos aristotélicos de mimesis e poiesis, isto é, de imitação e de representação, estabelecendo, portanto, que é a literatura uma forma de reconstrução da sociedade através da percepção individual do autor. Essa percepção encontra a

4 Entenda-se por Igreja primitiva aquela construída até o século IV d. C., culminando com a canonização dos textos bíblicos por Constantino, em 325, no Concilio de Niceia. Ver mais em Drobner (2003).

5 Derivado da palavra cana (kaneh), unidade de medida, Cânon pode ser compreendido como um meio de padrão e é utilizado para designar os livros legítimos que compõem o conteúdo bíblico (Gabel; Wheeler, 2003, p. 74) 
segunda proposição no momento em que se manifesta por meio da apropriação da linguagem e de recursos literários (Zabatiero; Leonel, 2011, p. 111).

A adoção da linguagem poética e metafórica no processo de "reconstrução" do mundo é também discutida por Paul Ricoeur que reencontra a ideia aristotélica de mimesis e poiesis e aborda a relação entre ficção e redescrição do mundo na perspectiva da hermenêutica bíblica, em uma conclusão da revelação da experiência humana comum:

Com efeito, [...] a referência ordinária da linguagem é abolida pela estratégia natural do discurso poético. Mas na medida em que essa referência de primeira ordem é abolida, é liberado um outro poder de dizer o mundo, embora em outro nível de realidade. Esse nível é o que a fenomenologia husserliana designou como "o mundo do vivo" (Lebenswelt) e que Heidegger chamou "ser no mundo". É um mundo que eclipsa os objetos manipuláveis, um mundo que esclarece a vida, um "ser no mundo" não manipulável, que me parece ser a contribuição ontológica fundamental da linguagem poética (Ricoeur, 2006, p. 177-178).

Reconhece-se, desse modo, que a Bíblia é literatura, porque estabelece proximidade com a sociedade, sem que a transcreva meramente, através de narrativas e figuras de linguagem, de elementos próprios como narradores, personagens, tempos e cenários definidos, de estilos literários então existentes, como no caso dos salmos em versos e das parábolas, e de estilos literários então inovadores, como foram os evangelhos, estilo característico da literatura do Novo Testamento (Zabatiero; Leonel, 2011).

Gabel e Wheeler (2003, p. 27), ao analisarem as formas literárias das escrituras, consideram que:

Todo exemplar de escritura é de um certo tipo. Ele se situa no âmbito de uma tradição formal particular e exemplifica essa tradição. [...] As inovações só conseguiram ampliar as fronteiras das formas tradicionais, sem se libertar delas por inteiro

As formas e estratégias literárias, do mesmo modo que as próprias palavras que compõem os textos, são essenciais à compreensão da mensagem e exprimem também intenções. A popularidade dos estilos literários ${ }^{6}$ demonstra que exerciam uma função na sociedade a que eram

6 Gabel e Wheeler (2003, p. 27-48) elencam como formas literárias presentes na literatura bíblica: as etiologias (atribuições de nomes), narrativas de nascimento, milagres, 
contemporâneos. A utilização dos recursos literários de acordo com a especificidade das ocasiões - em cultos e celebrações, por exemplo - revela, também, que a escolha de seu emprego era dotada de intenções maiores (Gabel e Wheeler, 2003, p. 28-29). Essa conclusão implica que os textos bíblicos e os estilos neles empregados sejam analisados em conjunto, visto que se conectam e adquirem novos contornos. A forma se modifica e adquire novo uso, de acordo com a mensagem geral que se pretende transmitir (Ricoeur, 2006, p. 194).

A Bíblia, portanto, quando tomada de forma independente da crença na mitologia que desenvolve, é, como qualquer outro livro, produto de um ou mais seres humanos que possuem a intenção de expressar-se por meio de suas línguas nativas e das formas literárias a eles disponíveis. Mesmo os fiéis, que acreditam tratar-se a Bíblia de uma transmissão de Deus ao seu povo, reconhecem que o seu registro se deu por mãos humanas, de forma que aos livros que compõem a compilação foram atribuídos a autores diversos. E, enquanto literatura, é um conjunto de textos produzidos por indivíduos pertencentes a determinadas regiões e épocas, seres humanos social e historicamente determinados (Gabel; Wheeler, 2003, p. 17-26).

Como salientam Zabatiero e Leonel (2011, p. 21), ao refletirem sobre a produção escrita dos textos bíblicos:

Nenhum texto "é" o fato que narra ou a situação da qual testemunha. Ele é uma 'representação' de um meio de comunicação que possui leis próprias. Em outras palavras, o processo de acesso a uma realidade do passado através da literatura é mediado por alguém que escreve sobre tal situação, expressando seu modo de vê-la ou determinado ângulo de entendimento.

Indubitavelmente, o conjunto bíblico não foi um registro realizado ao acaso, tampouco foi produto de um curto período ou de uma única mão. Resulta, pelo contrário, de esforços múltiplos ao longo de séculos, das compilações judaicas - registro de fatos e intervalos de tempo da história do povo judeu, que se iniciou por volta de 1000 a.C. - às compilações da era

teofanias (aparecimento de Iaweh); as histórias heroicas no Antigo Testamento, os evangelhos, parábolas, relatos de julgamentos, relatos de curas, sentenças, narrativas de nascimento, bem-aventurança, "ai de vós", comentários legais, alegorias, envio dos apóstolos e a cena da transfiguração no Novo Testamento. Não obstante, discorrem acerca das estratégias literárias, entre as quais, a hipérbole, a metáfora, o simbolismo, a alegoria, a personificação, a ironia dramática e a ironia linguística, o jogo de palavras e a poesia. 
cristã. Jesus Cristo era, antes de tudo, um mestre judeu que acreditava na Lei expressa através da Torá, mas que propunha-lhe nova forma de interpretação. Desse modo, a base histórica do que se tornaria o cristianismo era a literatura judaica, à qual, posteriormente, unir-se-iam textos próprios da nova religião, originados da mensagem transmitida por Jesus (Ehrman, 2015, p. 39-40).

Em determinado ponto do primeiro século da era cristã, algumas décadas após a alegada morte de Jesus Cristo, os pregadores de sua palavra deram início à literatura da religião que se formara com o mestre judeu. Os registros cristãos mais antigos remetem às cartas atribuídas a Paulo (Ehrman, 2015, p. 32). Os evangelhos, narrativas sobre a vida do mestre que iniciara esse projeto, vieram em seguida, na segunda metade do século. $\mathrm{O}$ registro de histórias repassadas oralmente originou livros que, posteriormente, constituiriam um dos conjuntos mais lidos da atualidade: a Bíblia.

A oralidade característica da propagação inicial da mensagem cristã abriu margem para que diferentes versões dos fatos fossem transmitidas às gerações seguintes. Uma religião em processo de expansão, no entanto, necessitava de organização e consenso quanto às crenças que a guiavam, de modo a se diferenciar das variadas religiões espalhadas pelo império e a unir igrejas sob a mesma fé. Através de orientações registradas em cartas, as quais eram lidas abertamente nas comunidades - compostas, em sua maioria, por indivíduos analfabetos -, a barreira do distanciamento físico era ultrapassada, e estabelecia-se um padrão na fé e na prática cristã (Ehrman, 2015, p. 33-39).

No processo de padronização da religião, determinados escritos foram tomados como oficiais para as crenças e práticas cristãs e configuraram as Escrituras. Todavia, mesmo sobre eles o tempo e as condições da época técnicas manuais de compilação, sujeitas a erros e modificações variáveis se impuseram, e as divergências fizeram-se presentes. Vários dos registros das Escrituras apresentavam contradições ou não se encontravam em conformidade com o que se acreditava ser a mensagem de Jesus, de modo que, entre eles, alguns foram selecionados e reunidos em um cânone (Ehrman, 2015, p. 39-53). 
A primeira produção de um cânone das Escrituras é atribuída à Marcião, cristão que defendia enfaticamente a separação entre a Lei mosaica e a fé em Jesus Cristo. Marcião apoiava o pensamento paulino de que a salvação somente seria alcançada através do evangelho - crença em Jesus -, e não obrigatoriamente da Lei mosaica, fornecida aos homens pelo Deus judaico. Reuniu, então, 11 livros que transmitissem a sua compreensão da mensagem de Jesus Cristo. Todavia, encontrava nas cópias vestígios do que acreditava ser interferência de "falsos crentes", motivo pelo qual acreditou ser imprescindível editar passagens que estivessem em desacordo com a sua interpretação (Ehrman, 2015, p. 43-44).

As modificações de Marcião não foram as primeiras da literatura cristã. Antes mesmo de sua seleção de livros sagrados, os escritos apresentavam modificações e falsificações por razões diversas. As técnicas variavam em cópia do estilo, alteração parcial do texto ou mesmo falsa atribuição de autoria. As motivações, em geral, consistiam no desejo de transmitir uma mensagem que não seria ouvida de outro modo. Um autor desconhecido não alcançaria o mesmo público que um autor conhecido ou que tivesse posição de relevância social. Portanto, para que a verdade de um escritor fosse conhecida, ele precisava, em inúmeros casos, fazer-se passar por outro (Ehrman, 2015, p. 43-46).

As falsificações podem não representar a vontade egocêntrica de um único autor que se deseja fazer conhecido. Pelo contrário, foram muitas vezes utilizadas por grupos em conflito com outros. Acerca das motivações de grupos religiosos, por exemplo, Ehrman dispõe que "algumas vezes a motivação para uma falsificação era menos política que religiosa - defender instituições ou práticas religiosas, ou as alegações da religião de alguém contra as do adversário" (2013, p. 34).

Alguns escritos foram modificados conforme as interpretações dos copistas, os quais nem sempre eram profissionais habilitados na arte da transcrição. Os copistas, por vezes, acreditavam que as palavras dos textos sagrados deveriam transmitir a mensagem que eles pensavam ser a intenção. Textos, então, que já haviam sido objetos de uma seletividade de fatos e moldados de acordo com um ponto de vista, sofriam novas alterações. Novas visões eram concedidas aos escritos através das escolhas dos copistas, que, enquanto indivíduos contextualizados, revelavam na 
intertextualidade de suas cópias não somente seus desejos como as necessidades sociais do ambiente em que se inseriam (Gabel; Wheeler, 2003, p. 49-58).

Assim, nas palavras de Gabel e Wheeler (2003, p. 23):

Os redatores são pessoas que confeccionaram uma versão acabada de um texto a partir dos materiais postos à sua frente; esses materiais podem consistir em versões alternativas completas, várias versões parciais ou até uma versão substancialmente completa, que só precisa de pequenas mudanças. Eles podem selecionar, reorganizar, acrescentar os vínculos necessários, inserir explicações e até criar um arcabouço narrativo ou expositivos de sua lavra para apresentar o material. [...] às vezes também usam a própria memória de fontes orais. [...] tentam produzir um manuscrito final, que, no entanto, mais tarde, pode tornar-se parte do material de outra redação.

O cânone não somente foi moldado por autores influenciados pelo tempo e espaço, como foi construído através de palavras selecionadas de acordo as intenções daqueles que as escreviam. Considerar apenas a autoria atribuída a cada escrito - muitas das quais desconhecidas -, portanto, não é o suficiente para uma interpretação literária da Bíblia. É imprescindível que se considerem as colaborações e intervenções ao longo dos anos de sua constituição, bem como as escolhas de redação, edição, formatação e ordem, as quais influenciaram o sentido transmitido pela obra. As intenções gerais da antologia bíblica modificam a mensagem de escritos que, isoladamente, apresentam diferenças estilísticas, de acordo com Gabel e Wheeler (2003, p. 21-25).

Consiste em equívoco acreditar que todas as modificações decorreram das intenções gerais que os copistas acreditavam - ou desejavam - querer transmitir à Bíblia. Pelo contrário, diversas foram as alterações realizadas por erros involuntários de transcrição, sobretudo diante do fato de que os primeiros copistas cristãos eram membros das assembleias, e não profissionais. Todavia, não se podem ignorar mudanças realizadas intencionalmente com o interesse de consolidar o pensamento de um grupo diante de divergências. Como Ehrman (2015, p. 159) destaca, “[...] há algo mais importante na tradição textual do Novo testamento do que meramente decidir o que o seu autor realmente escreveu. Há a questão de por que essas palavras vieram a ser mudadas e de como essas mudanças afetam os sentidos de seus escritos". 
Disputas formavam-se em função de interpretações e alterações. Entre os conflitos externos, havia a relação dos cristãos com os judeus nãocristãos e com os pagãos. Entre os conflitos internos, a questão da mulher. Enquanto algumas igrejas defendiam que os textos de Paulo pregavam relativa igualdade entre homens e mulheres e aceitavam que estas tivessem significativa participação na liderança religiosa, outras igrejas - as que saíram vitoriosas na construção do cânone - defendiam textos que pregavam o silenciamento das mulheres e que vedavam sua ativa participação dentro da instituição cristã. O que estudiosos como Bart D. Ehrman (2015, p. 187-215) e C. J. den Heyer (2008, p. 120) questionam é não somente a credibilidade dos textos escolhidos como oficiais, mas também as consequências que essa definição traria nos séculos seguintes.

\section{OS DIREITOS DAS MULHERES NOS PRÍMEIROS SÉCULOS DA ERA CRISTÃ}

Antes de abordar os problemas ocasionados pelas modificações dos textos bíblicos referentes ao papel das mulheres na sociedade, é necessário ambientá-las na época. Consoante Mondoni (2014, p. 24), nos primeiros séculos da era cristã, a maioria rica encontrava-se estabelecida nas cidades helênicas, centros culturais e de conhecimento. Nas camadas intermediárias, havia os trabalhadores autônomos. Abaixo deles, os operários temporários e diaristas, os mendigos e inválidos. Em questão de direitos, as mulheres se encontravam nas categorias mais inferiores, equiparadas aos menores e aos escravos.

Mulheres eram consideradas seres fracos e verdadeiros fardos no Império Romano. Como destaca o autor, "romanos do primeiro século zombavam dos cristãos por falarem e ouvirem as fracas mulheres" (Mondoni, 2014, p. 62). Impedidas de exercer profissões de prestígio, não somente deixavam de oferecer uma renda às suas famílias, como causavam ônus em função dos dotes exigidos para o casamento. A vergonha e os prejuízos ocasionados pela vinda de uma filha eram fatores que contribuíam para o alto número de infanticídio feminino.

Aquelas que não eram deixadas para morrer, cresciam para viver em uma sociedade caracterizada pela inferioridade legal feminina. O pouco poder de decisão que lhes era concedido - tal como o direito de aceitar ou recusar um pretendente escolhido pelo seu genitor - acabava por se tornar 
ineficaz diante de leis que condenavam com a morte a desobediência de uma mulher (Mondoni, 2014, p. 62).

A restrição de direitos não era característica exclusiva da cultura judaica, mas amplamente perpetuada na extensão do antigo Oriente Próximo. A equiparação com menores e escravos tornava as mulheres legalmente obedientes aos chefes das famílias. O tratamento que recebiam, independentemente da região, não se afastava do tratamento dispensado a uma propriedade. Quando solteiras, deviam obediência aos pais; quando casadas, aos maridos. E uma vez estabelecido o casamento, a elas era vedada a possibilidade de divórcio - privilégio masculino aplicado de diferentes modos na localidade. Paul Johnson (2014, p. 96-97) cita, como exemplo, o código penal babilônico, no qual as mulheres estavam sujeitas ao afogamento caso repudiassem seus maridos.

Não foi surpresa, portanto, que as mulheres constituíssem apoio significativo a uma religião que prometia um cenário de vida diverso. $\mathrm{O}$ cristianismo propunha uma alternativa à invisibilidade com que conviviam no antigo Oriente Próximo. Johnson (2014, p. 90) escreve que as mulheres "tinham pouco ou nenhum status a não ser que se casassem com governantes, e mesmo então sua posição era precária. Podiam ser descartadas - 'afastadas' era o termo empregado em documentos legais segundo o capricho dos maridos”. Jesus, segundo os evangelhos, pelo contrário, lhes oferecia não somente a igualdade perante os olhos de Deus como a oportunidade de exercerem papéis de importância na promoção da mensagem divina.

De acordo com Ehrman (2015, p. 189):

\begin{abstract}
A maioria dos pesquisadores está convicta de que Jesus proclamou o Reino vindouro de Deus, no qual não haveria mais injustiça, sofrimento ou mal, no qual todos, ricos e pobres, escravos e libertos, homens e mulheres, estariam em pé de igualdade. Essa mensagem de esperança demonstrou-se particularmente atraente para aqueles que, naquele tempo, eram excluídos - o pobre, o doente, o banido. $E$ as mulheres.
\end{abstract}

Paul Johnson, ao abordar a participação das mulheres no projeto cristão, escreve que uma das razões pelas quais as mulheres ouviam atentamente as palavras de Jesus era o fato de que, diferentemente de como ocorria conforme as interpretações padrões do judaísmo, Jesus as colocava no "centro junto com os homens, partilhando igualmente seus deveres e 
seus consolos" (2014, p. 96). A história do cristianismo contava, ainda, com personagens femininas de relevância, como a mãe de Jesus, Maria, "uma parte indispensável de sua Encarnação” (2014, p. 96).

Através da passagem de Lucas (21, 1-4) e de Marcos (12,41-44), sobre a verdadeira atitude religiosa, Johnson (2014, p. 90) exemplifica o significado do cristianismo para os excluídos - grupo no qual se encontravam as mulheres - e o porquê da atração na mensagem do messias. No referido trecho, uma viúva, crente no poder de Jesus, busca-o em meio à multidão. Jesus louva-a, porque vê na idosa o coração generoso daqueles que compreendem o que é necessidade e, ainda assim, contribuem com sua bondade. A literatura é, então, utilizada para demonstrar que Jesus enxergava as pessoas mesmo quando a sociedade não o fazia. Uma mulher idosa, indigna de visibilidade perante o império, foi considerada digna de louvor, porque o mestre de uma nova religião vira apenas a sua generosidade. Queriam, com isso, dizer os cristãos que a humildade e a bondade superavam a insignificância social dos indivíduos.

As inovações propostas pelo cristianismo conquistaram adeptos por cada vez mais regiões do império, estabelecendo, nos primeiros séculos da religião, um processo de verdadeira gradação da simbiose entre religião em Estado. Esse processo culminou na validação do cristianismo e em sua oficialização como religião imperial em 380 d.C., sob o governo de Teodósio. A religião moldava a vida e a concepção individual e social, acabando por estar intrinsecamente interligada também à vida política do Império. Por esse motivo, a intervenção na esfera religiosa era vista como essencial à manutenção da unidade política. Sob a perspectiva do direito, tomada como norte da vida imperial, a adoção do cristianismo católico como religião do império acarretou, de acordo com Mondoni (2015, p. 61), "uma evolução lenta e profunda da legislação romana, que se inspirou não tanto no estoicismo e no neoplatonismo, mas sim na ética cristã (maior respeito à pessoa e à vida humana)".

As práticas humanizadas incluíam uma relativa modificação na concepção da figura feminina e promoveram mudanças significativas na sociedade imperial romana, tais quais a equiparação do assassinato de uma criança a mando da autoridade paterna - ocorrida em maior número quando a prole era feminina, como observado anteriormente - ao 
patricídio, a proibição do abandono ou exposição de crianças e o reconhecimento da dignidade das mulheres por meio da máxima paulina de que, em Cristo, "não há mais diferença [...] entre homem e mulher” (Gl 3, 28).

No tocante ao casamento, o cristianismo propunha que fosse indissolúvel e elevava-o ao nível sagrado. Mateus escreve:

Alguns fariseus se aproximaram de Jesus, e perguntaram, para o tentar: 'É permitido ao homem divorcia-se de sua mulher por qualquer motivo?' Jesus respondeu: 'Vocês nunca leram que o Criador, desde o início, os fez homem e mulher? E que ele disse: 'Por isso o homem deixará seu pai e sua mãe, e sua mãe, e se unirá à sua mulher, e os dois serão uma só carne'? Portanto, eles já não são dois, mas uma só carne. Portanto, o que Deus uniu, o homem não deve separar (19, 3-7).

Paul Johnson (2014, p. 96) interpreta a condenação do divórcio como uma forma de proteger as mulheres, principais vítimas da dissolução, sobretudo porque a escolha era unicamente facultada ao marido descontente com a união. Observe-se o questionamento realizado na passagem de Mateus: "É permitido ao homem divorcia-se da mulher por qualquer motivo?” (19, 3). A pergunta evidencia que a permissão do divórcio era restrita aos homens e poderia ser justificada por motivos apenas pertinentes a ele, não sendo facultado às mulheres.

A presença feminina na literatura bíblica, porém, não se limita apenas a personagens externas ao círculo de promoção do cristianismo ou de pouco relevância no processo de consolidação da religião. De fato, segundo o cânone bíblico, os discípulos eram todos homens, e não se poderia esperar cenário diverso dado o contexto cultural e social de submissão feminina7. Ainda assim, os Evangelhos indicam que mulheres acompanhavam Jesus em sua trajetória, bem como "davam suporte financeiro a ele e a seus discípulos, agindo como patronas de seu ministério de pregação itinerante” (Ehrman, 2015, p. 189).

Lucas registra em seu Evangelho:

[...] Jesus andava por cidades e povoados, pregando e anunciando a Boa Notícia do Reino de Deus. Os Doze iam com ele, e também algumas mulheres [...]: Maria,

7 Posição diferente dos evangelhos apócrifos, que - como o evangelho de Maria Madalena destacam a proeminência da participação feminina. Ver mais em Bock (2007). 
chamada Madalena, [...] Joana, mulher de Cuza, alto funcionário de Herodes; Susana, e várias outras mulheres, que ajudavam a Jesus e aos discípulos com os bens que possuíam $(8,1-3)$.

Nas cartas de Paulo, várias são as menções a mulheres que tiveram significativa participação na liderança da igreja após a morte de Jesus Cristo:

Como missionárias, escritoras e mestras, as mulheres participaram ativamente da vida da Igreja na Antiguidade: Tecla foi companheira de São Paulo em suas viagens, Proba foi poetisa, outra Proba foi administradora de negócios, Mônica e Perpétua foram mães, Marcela, Paula e Estóquia foram estudiosas e contemplativas, as mártires Blandina e Felicidade eram servas domésticas, Macrina foi guia espiritual e mestra (Mondoni, 2014, p. 44).

Paulo comumente faz referência à participação ativa das mulheres, quadro que se justificava segundo sua mensagem de igualdade. Acerca dessa, no entanto, é preciso se atentar ao detalhe de que o autor não promovia uma revolução verdadeira no posicionamento das mulheres ao permitir sua participação em lideranças da vida religioso ou ao pregar a igualdade perante Deus.

Paulo acreditava que a vinda do Reino de Deus se daria em breve. Assim, a transmissão da mensagem na terra era intermediária e temporária, motivo pelo qual ele não via razão em modificar os relacionamentos terrenos, embora pregasse que todos devessem ser tratados com dignidade. Em sua concepção - ainda que, Jesus não favorecesse homem ou mulher, escravo ou liberto -, cada um deveria exercer o papel que lhe fora atribuído. Embora Paulo não faça referência direta à situação da mulher, a passagem "Cada um permaneça na condição em que se encontrava quando foi chamado" (1Cor 7,20 ) pode ser estendida à sua concepção do sexo feminino.

Apesar da mensagem de igualdade, as cartas de Paulo apresentavam também passagens que denotavam um sentido muitas vezes contraditório a esse princípio, a exemplo da primeira carta a Timóteo, sobre o dever de silêncio das mulheres (1Tm 2, 9-15). Tal ambivalência - textos que abordavam a participação das mulheres sob o argumento da igualdade perante Deus sem retirar, contudo, o dever de submissão enquanto seres do sexo feminino - gerou diferentes interpretações nas igrejas dos tempos 
seguintes, algumas das quais se inclinariam na defesa do princípio da igualdade, e outras, no dever de subserviência das mulheres aos homens. Dentro das últimas, ao invés do exercício de liderança, às mulheres seriam destinados papéis menores e que contribuíssem para que permanecessem silenciadas.

Desse modo, a importante contribuição feminina nos primeiros séculos da Igreja Cristã e a influência que esse registro poderia fornecer ao papel social exercido pelas mulheres foram ocultadas por outras versões da história. Mesmo que a responsabilidade feminina no crescimento da religião tenha sido tão grande quanto a dos homens, apenas a última foi evidenciada no cânone cristão e, consequentemente, na prática cristã.

Conforme Mondoni (2014, p. 33), a história da participação feminina na construção e na administração da Igreja "não foi contada, porque tenderam a trabalhar de formas que foram ignoradas pelos relatos históricos-padrão". Não obstante a história tenha sido ignorada, pode ter sido modificada, como se verá adiante, conforme os interesses daqueles que realizaram o seu registro.

\section{O ESFORÇO NO CÂNONE PARA A SUPRESSÃO DE DIREITOS DAS MULHERES}

A razão no grande conflito acerca do papel da mulher na literatura canônica reside no fato de que, no período inicial do projeto de pregação cristã, elas, de fato, exerceram papéis de importância e destaque, ainda que o feito fosse incomum à sociedade da época. Não somente constituíram uma parcela significativa do público de Jesus Cristo, como assumiram posições de liderança na expansão do cristianismo pelo Império Romano. As passagens bíblicas revelam que também indivíduos do sexo feminino acompanhavam Jesus em suas pregações e auxiliavam os apóstolos após a sua morte - ou mesmo eram apóstolos, conforme determinadas interpretações.

O processo de compilação dos evangelhos e epístolas, como expressa Ehrman (2015, p. 187), era, de modo geral, um processo "conservador". Tanto os copistas cristãos dos séculos iniciais como os copistas profissionais da Idade Média não pretendiam modificar a tradição textual do que transmitiam através de suas cópias. Contudo, a concepção de conservação que eles possuíam podia, em determinados momentos, contrapor-se à 
mensagem pretendida com os textos que copiavam, caso estes propusessem reflexões incomuns ou revolucionárias ao período.

A cultura cristã promovida pelos textos copiados sob esse método de conservação da mensagem geral, baseada no controle e no temor sobretudo a assuntos de cunho sexual, tenderam à desvalorização simbólica e social da figura feminina, reduzindo-a à figura materna subserviente. Constantemente invocada, a diferenciação biológica serviu como justificativa ao propósito de exclusão da mulher da esfera pública e da reiteração de sua inferioridade social e política (Nunes, 2008).

Referindo-se à interrogação de Michelle Perrot acerca do papel feminino nos primeiros séculos da Igreja Cristã, Nunes destaca:

[...] predomina a representação da mulher como fonte de pecado, da sexualidade como eterna tentação, assim como do casamento como um estado inferior. Em que medida estes dados fundamentais mudaram? É o que se pergunta muitas vezes, diante do rigor das posições atuais da Igreja. [...] Por que esta obsessão, e mesmo este ódio da carne, da sexualidade, e esta profunda desconfiança da mulher no cristianismo? Desconfiança que informou toda a cultura ocidental judaico-cristã (Perrot apud Nunes, 2008, p.73).

As modificações mais profundas envolvendo a temática feminina e seus direitos dentro da instituição ocorreram nas cartas paulinas, que visavam a orientar a prática religiosa e abordavam a liderança na religião, incluindo líderes mulheres. No entanto, também foram objeto de discussões outras passagens do cânone, como a descoberta do túmulo vazio de Jesus por Maria Madalena, personagem que, nos quatro Evangelhos canônicos, faz-se presente nesse episódio.

A ressurreição é considerada "o primeiro momento decisivo na cristologia” (Ehrman, 2014, p. 275), isto é, no entendimento de Cristo. Antes de ressuscitar, Jesus era um homem como todos os que se disponibilizavam a ouvi-lo. Foi a experiência de retornar dos mortos que o transformou de um pregador apocalíptico no Filho do Homem e revelou o aspecto divino inerente a ele. Seu retorno foi a força motriz do cristianismo, e a primeira testemunha de seu feito foi uma mulher. A participação de Maria Madalena na literatura da ressurreição de Jesus demonstra que as mulheres possuíam representação nas comunidades cristãs primitivas. 
Ainda que se queira alegar que houvesse alguma falsificação no relato, segundo critérios de verificação dos fatos, não haveria por que alterar a narrativa verificada nos Evangelhos de Mateus (28, 1-10), Marcos (16, 1-8), Lucas (24, 1-12) e João (20,1-2). Não se encontram benefícios em colocar mulheres como as primeiras testemunhas do retorno de Cristo em uma sociedade que as consideravam indignas de confiança e que invalidavam seu testemunho.

No entanto, se há consenso quanto à veracidade dos registros textuais que narram a ressureição de Jesus, o mesmo não ocorre em relação a determinadas cartas paulinas. O que estudiosos concordam, pelo contrário, é que houve alterações e falsificações nas produções de Paulo com o propósito de suprimir a participação da mulher na Igreja. Como observado anteriormente, a ambivalência dos textos paulinos acerca do desempenho de papéis estabelecidos socialmente permitiu que diferentes grupos interpretativos se formassem e disputassem o controle sobre a história que seria legada às demais gerações, e parece improvável que os copistas responsáveis pela distribuição da literatura bíblica tenham se mantido afastados desses conflitos. Inseridos nos debates, interviram de forma a, na maior parte das vezes, alterar os textos para "limitar o papel da mulher e diminuir a sua importância para o movimento cristão" (Ehrman, 2015, p. 193).

Ao escrever suas cartas, Paulo, provavelmente, não previu os problemas que seu legado deixaria quanto aos direitos das mulheres dentro da religião - e, consequentemente, da sociedade de modo geral. Escrever sobre mulheres detentoras de uma parcela de poder dentro de uma instituição, ainda que não em nível de plena igualdade com os homens, gerou desconfortos e desavenças nas gerações seguintes, indagações para as quais não se possuíam respostas, uma vez que não foram abordadas pelo autor. A solução encontrada, então, foi fornecer uma resposta sob a sua autoridade, atribuindo-lhe textos que, conforme estudos, não faria sentido terem sido escritos por ele.

De acordo com Ehrman (2013, p. 108-109), a teoria mais provável é a de que:

As igrejas de Paulo estavam divididas de muitas formas [...]. Uma das divisões envolvia questões de sexo, sexualidade e gênero. Alguns cristãos paulinos achavam 
que as mulheres deveriam ser tratadas como iguais, tendo status e autoridade iguais aos homens, já que Paulo dissera que não 'há homem nem mulher, pois todos vós sois um em Cristo Jesus' (Gl 3,28). Outros cristãos paulinos pensavam que as mulheres eram iguais aos homens apenas 'em Cristo', com o que queria dizer 'em teoria', não em realidade social. Esses cristãos estavam ansiosos para reduzir a ênfase de Paulo nas mulheres, e um deles decidiu escrever um conjunto de cartas, as pastorais, que autorizava seu ponto de vista em nome de Paulo.

Mesmo na menção de mulheres ativamente participativas da missão cristã, houve discussões. Isso porque, embora mais membros homens fossem nomeados como membros das congregações cristãs, as mulheres mencionadas por Paulo não eram tratadas com inferioridade, como se poderia esperar, mas consideradas elementos tão importantes quanto eles nas comunidades cristãs emergentes. É o que se pode constatar, por exemplo, nas saudações finais de Paulo em sua carta aos Romanos, em que o primeiro nome a ser citado é o da diaconisa Febe.

Recomendo a vocês nossa irmã Febe, diaconisa da igreja
de Cencréia. [...] Dêem a ela toda a ajuda que precisar,
pois ela tem ajudado muita gente e a mim também.
Saudações a Prisca e Áquila, meus colaboradores em
Jesus Cristo, que arriscaram a própria cabeça para salvar
a minha vida [...]. Saúdem também a igreja que se reúne
na casa deles. [...] Saúdem Andrônico e Júnia, meus
parentes e companheiros de prisão, eles são apóstolos
importantes e se converteram a Cristo antes de mim. [...]
[...]Saúdem Trifena e Trifosa, que trabalharam pelo
Senhor. Saúdem a querida Pérside, que trabalha muito
pelo Senhor. Saúdem Rufo [...] e sua mãe. [...]. Saúdem
Filólogo e Júlia, Nereu e sua irmã [...] (Rm 16,1-15).

O trecho transcrito, embora curto, apresenta grandes problemáticas à questão das mulheres. Não obstante Paulo saúde primeiro uma mulher, inclui outra no grupo de apóstolos, ao escrever sobre Andrônico e Júnia. Alguns intérpretes, incapazes de aceitar uma mulher no grupo de apóstolos, tentaram justificar o versículo, afirmando que Júnia seria um homem. No entanto, Júnia era um nome tipicamente feminino, e não se encontram relatos da existência de homens chamados Júnias na região. Outros intérpretes, então, conscientes de que a justificativa do gênero do nome não era plausível, fugiram do imbróglio ao alterar os textos para "saudai Andrônico e Júnia, meus parentes; saudai também meus companheiros de 
prisão, apóstolos eminentes” e, assim, desconectar Júnia da posição de apóstolo (Ehrman, 2015, p. 195).

Exemplo menor, mas não irrelevante, encontra-se no posicionamento dos nomes de Prisca e Áquila, casal recorrente também no livro de Atos. Alguns copistas entenderam que a anterioridade da menção ao nome de Prisca evidenciaria maior importância que seu marido Áquila, por ser prática comum iniciar com o nome do homem. Com o intuito de anular essa possível interpretação, modificaram a ordem, em algumas versões do escrito, para que o homem estivesse em destaque (Ehrman, 2015, p. 190196).

As discussões mais complexas envolvendo as cartas paulinas, entretanto, certamente se encontram não nas menções a mulheres, mas em passagens dedicadas à organização da instituição, nas quais se definiam permissões e proibições às mulheres dentro dos ritos, tal qual o caso da primeira carta a Timóteo e da primeira carta aos Coríntios.

Em sua primeira carta a Timóteo, colega deixado como líder na Igreja de Éfeso, Paulo o instrui quanto ao comportamento das mulheres:

Durante a instrução, a mulher deve ficar em silêncio, com toda a submissão. Eu não permito que mulher ensine ou domine o homem. Portanto, que ela conserve o silêncio. Porque primeiro foi formado Adão, depois Eva. E não foi Adão que foi seduzido, mas a mulher que, seduzida, pecou. Entretanto, ela será salva pela sua maternidade, desde que permaneça com modéstia na fé, no amor e na santidade (1Tm 2, 11-15).

Quando analisada isoladamente, a carta pode não produzir estranhamento. Todavia, pregar o silenciamento das mulheres e a proibição de atuarem no ensino da religião parece ser contraditório às menções realizadas em outros textos também de autoria de Paulo, em que não só reconhece como saúda o trabalho missionário por elas realizado. O silenciamento e a submissão promovidos através da primeira carta a Timóteo tornariam impossível a atuação das mulheres dentro da Igreja, algo que Paulo registrara anteriormente, pois estariam impedidas até mesmo de rezar pública e abertamente.

Não obstante, tal determinação se opõe até mesmo à ideia de igualdade defendida por Cristo, uma vez que exige das mulheres não somente a fé, como a maternidade para a salvação. Em função dessas e de outras contradições, de passagens incoerentes quando contrapostas ao 
cenário ou à narrativa paulina em geral, muitos estudiosos se mostram convencidos de que se trata de uma falsificação em nome de Paulo, do mesmo modo que a segunda carta a Timóteo.

Ainda que não haja autoria explícita nas cartas pastorais - assim denominadas porque instruíam sobre os deveres pastorais e ministeriais a Timóteo, existem indícios de que o autor possuía a intenção de se fazer passar por Paulo. Ehrman (2013, p. 100) menciona a publicação, em 1807, de uma carta de Friedrich Scheleiermacher, na qual o estudioso defende que, apesar da tentativa de se atribuir a autoria a Paulo, as cartas a Timóteo utilizam palavras e ideias em contradição com as demais cartas paulinas. Ademais, o texto mostra-se também anacrônico, ao apresentar críticas características do século II. Logo, não poderia pertencer a Paulo, autor do primeiro século da era cristã.

Ehrman (2013, p. 107-108), a respeito do tema, cita, também, Dennis MacDonald, que desenvolve a hipótese de que a falsificação das epístolas pastorais serviu não somente ao propósito de minimizar o papel das mulheres na literatura bíblica, mas ao de se opor, especificamente, às histórias sobre Tecla ${ }^{8}$, uma convertida que ensinava e encontrava-se em posição de autoridade. MacDonald supõe que o autor de 1Timóteo e 2Timóteo teria conhecimento dos relatos que seriam registrados posteriormente em Atos de Paulo - escrito entre setenta e oitenta anos depois das pastorais - e haveria falsificado cartas em nome do apóstolo com a intenção de contradizê-los. Essa teoria, porém, não é a mais aceita, em razão das datas, como se verifica. A hipótese mais plausível consiste, logo, na existência de conflitos de interpretação entre Igrejas divergentes e na falsificação como método de hegemonizar a crença de uma das vertentes.

Em Coríntios, novamente a problemática é levantada. Corinto, uma cidade portuária do sul da Grécia, talvez fosse o cenário mais distinto da realidade feminina. A reunião de pessoas proveniente de locais diversos concedia à cidade, além da fama imoral que seria combatida nas cartas de Paulo, um caráter de intensa comunicação cultural. Junto ao culto de Afrodite, por exemplo, encontrava-se o culto à deusa egípcia Ísis, ambas

8 Tecla é uma personagem do livro apócrifo - não oficial - intitulado Atos de Paulo e teria se convertido ao cristianismo após conhecer o apóstolo, tornando-se sua seguidora (Ehrman, 2013, p. 107-108; Mondoni, 2014, p. 44). 
importantes figuras mitológicas femininas. O culto a Ísis, conforme escreve C. J. Den Heyer, teria importante influência no modo como as mulheres, em especial, encarariam o cristianismo em Corinto e também nas advertências de Paulo dirigidas à comunidade. Quando Den Heyer (2009, p. 95) afirma "de Ísis dizia-se que 'outorgou o mesmo poder às mulheres que aos homens", o autor parece revelar que a ideia de igualdade entre homens e mulheres já existia na cidade de Corinto.

As duas cartas aos Coríntios são consideradas autênticas, isto é, de autoria genuína de Paulo. Todavia, quando analisadas, verifica-se que possuem trechos em contradição com outras pregações do apóstolo. Em uma passagem, por exemplo, Paulo parece ir contra a mensagem de igualdade expressa na carta aos Gálatas, ao abordar a necessidade de utilização do véu para as mulheres e novamente invocar a submissão feminina:

[...] quero que vocês saibam que a cabeça de todo homem é Cristo, que a cabeça de toda mulher é o homem, e que a cabeça de Cristo é deus. [...] toda mulher que reza ou profetiza de cabeça descoberta, desonra a sua cabeça; é como se estivesse com a cabeça raspada. Se a mulher não se cobre com o véu, mande cortar os cabelos. Mas, se é vergonhoso para uma mulher ter os cabelos cortados ou raspados, então cubra a cabeça.

[...] o homem não foi criado para a mulher, mas a mulher foi criada para o homem. Sendo assim, a mulher deve trazer sobre a sua cabeça o sinal de dependência, por causa dos anjos (1Cor 11,2-10).

Ainda em 1Coríntios, retoma-se a obrigação da mulher de permanecer em silêncio, uma contradição com as práticas registradas em outras passagens, conforme analisado no estudo da primeira carta a Timóteo:

Que as mulheres fiquem caladas nas assembleias, como se faz em todas as igrejas dos cristãos, pois não lhes é permitido tomar a palavra. Devem ficar submissas, como diz também a Lei. Se desejam instruir-se sobre algum ponto, perguntem aos maridos em casa; não é conveniente que as mulheres falem nas assembleias (1Cor 14, 34-35).

Den Heyer (2009, p. 120), comenta a passagem, invocando a mensagem de igualdade presente na carta aos Gálatas, escrita pouco tempo depois:

Paulo, sem dúvida, levava muito à série sua chamada à ordem na comunidade; porém, os abusos estão sempre à espreita e assim tem ocorrido durante séculos. Às 
mulheres tem sido assinalado um papel secundário, ao longo da história da Igreja, que é fundamentado na observação de Paulo [...]. O texto é absolutamente claro. Porém, não se encaixa aqui. [...] $\mathrm{O}$ apóstolo não era, em absoluto, um misógino [...]. Nada nos sugere que Paulo pensasse manter em silêncio [...] mulheres ou que lhes negasse uma função própria na comunidade cristã primitiva. Consequentemente, temos de pensar que motivos poderia ter para reagir de maneira tão diferente em sua carta à comunidade de Corinto.

Ainda que Corinto apresentasse uma tradição feminina que se destacasse, dadas as tradições da região, Den Heyer (2009, p. 122) não enxerga como plausível a hipótese de que Paulo teria inserido a advertência apenas para silenciá-las, sobretudo por se tratar de um quadro singular. Assim como outros pesquisadores, concorda que a teoria mais provável seja a de que o trecho assinalado tenha sido originado de uma alteração posterior a Paulo.

A semelhança entre o cerceamento do direito de fala dentro dos ritos, presente em 1Coríntios e em 1Timóteo, gera questionamentos, uma vez que a primeira carta a Timóteo provavelmente não foi escrita por Paulo, enquanto a primeira carta aos Coríntios é considerada uma carta autêntica. Ehrman (2015, p. 193) apresenta a teoria de que houve, no processo de compilação, um erro quanto às notas marginais, devido a uma mudança de posição da passagem, que, em alguns manuscritos gregos e latinos, não se encontra no versículo 34, mas depois do versículo 40. Supõe-se, assim, que a origem dessa incoerente passagem esteja em uma nota marginal baseada nos textos de 1Timóteo, inserida em lugares diferentes da primeira carta aos Coríntios e incorporada ao texto com o passar dos anos.

A hipótese é reforçada pela não coadunação com o contexto imediato da passagem, que se propõe, nos versículos anteriores e posteriores, a discutir o papel dos profetas, tema que é interrompido para abordar o silenciamento das mulheres. Ainda, na mesma carta, quando da controversa passagem acerca da utilização do véu, Paulo permite que as mulheres rezem ou profetizem, desde que com a cabeça coberta.

Quando da consolidação do cânone, ambas as versões - a que minimizava a participação feminina e a que evidenciava o direito de participação ativa na vida religiosas - circulavam pelo Império. Ainda que apenas uma delas tenha sido considerada a "verdadeira" para o 
cristianismo, não foi aceita unanimemente por todos os membros, razão pela qual hoje se pode realizar essa comparação de dados e reflexão. Do contrário, a versão alternativa, renegada pela instituição religiosa, poderia ter-se perdido.

Apenas uma alteração justificaria coerentemente a grande mudança de visão em textos tão próximos de Paulo. Acima de tudo, uma modificação que, como as demais, teve a intenção de minimizar o papel das mulheres e enfatizar seu dever de submissão, obediência e silêncio. As consequências seriam vistas nos séculos seguintes, uma gradativa modificação na atuação feminina e em seus direitos. E somente na contemporaneidade, voltaria a ganhar força o projeto de inserção das mulheres em cargos de liderança dentro da igreja - e também da sociedade.

A proposta de um diálogo entre feminismo e religião ganhou força nas últimas décadas, e a história das religiões é vista como um meio de compreensão e elucidação de conflitos contemporâneos. A construção histórica foi seletiva no que concerne às mulheres, construídas historicamente sob um véu de invisibilidade. Todavia, estudar as fontes históricas e os processos a que elas foram submetidas é uma forma de escrever uma história consciente de seu passado definido pelas relações de gênero (Nunes, 2001).

Como sugere Sabine Demel (2014, p. 101), ao refletir sobre necessidade de reformulação da posição da mulher dentro da cúria:

Que sinalização positiva não teria dentro das igrejas locais e também na sociedade se a iminente reforma da cúria romana for utilizada não só para colocar, singularmente, mulheres dentro da cúria, mas também de forma sistemática para trabalhar numa equiparação de homens e mulheres.

\section{CONSIDERAÇÕES FINAIS}

A Igreja Cristã, principalmente a vertente católica apostólica romana, foi, por muitos anos, a instituição definidora da moral ocidental e, consequentemente, da conduta dos indivíduos em sociedade, de modo que os ensinamentos da religião eram refletidos na vida cotidiana. A separação da mitologia na condução do Estado é um pensamento moderno, advindo, sobretudo, do racionalismo e da revolução burguesa. Mesmo antes de Teodósio instituir o cristianismo católico como religião oficial do império, a relação do governante com a figura divina era estreita. Imperadores eram 
indivíduos adotados pelos deuses que deveriam ser cultuados pela população.

A religião imperial deu lugar ao cristianismo, visto como medida de unificação do império, uma vez que atraía os cidadãos e não cidadãos romanos com sua mensagem de dignidade humana, não obstante contribuísse para o moral da figura do imperador. Apresentava ideais revolucionários, que encantavam sobretudo aqueles mais carentes de direitos, como mulheres, crianças, pobres e escravos. Essa mensagem, porém, ao mesmo tempo em que apresentava a vantagem de agregar maior número de fiéis, era desvantajosa, pois tornava o cristianismo mais fraco diante daqueles que se opunham a ele, não obstante fosse de encontro a tradições enraizadas na cultura da região.

A origem oral dos registros apenas contribuiu para a divergência de interpretações e interesses que marcariam a constituição do cânone cristão. Os copistas responsáveis pelo legado não somente escolheram textos que melhor atendessem aos seus interesses conservadores, ainda que em certa divergência ao ideal de igualdade que se promovia, como atuaram no sentido de modificar passagens que pudessem representar uma ameaça à interpretação da Bíblia que desejavam fosse feita.

Nesse processo, aqueles que constituíram, inicialmente, a parte majoritária dos seguidores viram ser suprimida uma parcela dos direitos que lhes poderiam ser concedidos. Assim foi com as mulheres, que, embora tenham sido consideradas dignas de respeito e iguais perante Deus, foram silenciadas e impedidas de participar da liderança de uma religião que ajudaram a promover. Os esforços dos que escreveram o cânone foram no sentido de apagar a participação das mulheres na missão cristã, de retirarlhes o direito de fala e de postergar a igualdade ao Reino vindouro.

A submissão feminina não é novidade apresentada pelo cristianismo, por óbvio, como se observa ao abordar a situação a que estavam submetidas as mulheres do antigo Oriente Próximo antes do advento da religião cristã. Ainda assim, é necessário evidenciar de que modo a literatura bíblica, tão cara à história do direito ocidental, foi direcionada à restrição dos direitos da mulher. Compreender as influências produzidas na sociedade ocidental pelas escolhas literárias que a moldaram é fundamental para que novas 
mudanças sejam realizadas nesse âmbito, na atualidade, principalmente mudanças de interpretação.

Imprescindível é observar que a restrição de direitos às mulheres não se limitou à vida religiosa. Não se pode pretender que a visão da Igreja acerca das mulheres não tenha exercido influência em outras esferas, sobretudo diante da ligação entre moral e direito. Se a figura divina regia a moral por meio de sua mensagem, expressa através da Bíblia, a definição do papel das mulheres no cânone, portanto, expandia-se para além do papel que elas exerciam dentro da instituição religiosa, atingindo seu papel na sociedade de modo geral.

Como adverte Nunes (2008), talvez o diálogo entre um feminismo que propõe a liberdade individual e um cristianismo que preza o papel coletivo pelos moldes de seus dogmas seja algo impossível, dadas as contradições que pode gerar. Todavia, isso não impede que as bases dessa influente religião sejam analisadas com o propósito de compreender uma realidade e, porventura, modificá-la.

Analisadas as escolhas realizadas pela Igreja Primitiva, verifica-se o preterimento de textos que mais se aproximavam do genuíno em favor de textos coadunados aos propósitos conservadores da instituição, ainda que em contradição a algumas das propostas, e constata-se ser inegável o esforço de suprimir direitos das mulheres. Desse modo, cabe à sociedade contemporânea conscientizar-se de tal fato e promover a desconstrução desse legado no tocante ao papel e aos direitos da mulher.

\section{REFERÊNCIAS}

ATOS DOS APÓSTOLOS. In: Bíblia sagrada. Tradução de Ivo Storniolo e Euclides Martins Balancin. São Paulo: Paulus, 1990. p. 1388-1439.

BOCK, Darrell L. Os evangelhos perdidos: a verdade por trás dos textos que não entraram na Bíblia. São Paulo, Thomas Nelson Brasil, 2007.

CORÍNTIOS, 1. In: Bíblia sagrada. Tradução de Ivo Storniolo e Euclides Martins Balancin. São Paulo: Paulus, 1990. p. 1460-1479.

DEMEL, Sabine. Mulheres assumem a liderança - agora também na cúria romana! Revista Concillium, n. 353, p. 91-101, 2014.

DROBNER, Hubertus R. Manual de patrologia. Petrópolis: Vozes, 2003.

EHRMAN, Bart D. Quem escreveu a Bíblia?: por que os autores da Bíblia não são quem pensamos que são. Tradução de Alexandre Martins. Rio de Janeiro: Agir, 2013. 288 p. 
EHRMAN, Bart D. Como Jesus se tornou Deus. Tradução de Lúcia Britto. São Paulo: Leya, 2014. 544 p.

EHRMAN, Bart D. O que Jesus disse? O que Jesus não disse?: quem mudou a Bíblia e por quê? Tradução de Marcos Marcionilo. 2. ed. Rio de Janeiro: Agir. 2015. 240 p.

GABEL, John B.; WHEELER, Charles B. A Bíblia como literatura: uma introdução. Tradução de Adail Ubirajara Sobral, Maria Stela Gonçalves. 2. ed. São Paulo: Loyola, 2003. 264 p.

GÁlATAS. In: Bíblia sagrada. Tradução de Ivo Storniolo e Euclides Martins Balancin. São Paulo: Paulus, 1990. p. 1493-1500.

HEYER, C. J. den. Paulo: um homem de dois mundos. Tradução de Luiz Alexandre Solano Rossi. São Paulo: Paulus, 2009. 222p.

JOÃO. In: Bíblia sagrada. Tradução de Ivo Storniolo e Euclides Martins Balancin. São Paulo: Paulus, 1990. p. 1352-1387.

JOHNSON, Paul. Jesus: uma biografia de Jesus Cristo para o século XXI. Tradução de Alexandre Martins. Rios de Janeiro: Nova Fronteira, 2014. 168 p.

LUCAS. In: Bíblia sagrada. Tradução de Ivo Storniolo e Euclides Martins Balancin. São Paulo: Paulus, 1990. p. 1308-1351.

MARCOS. In: Bíblia sagrada. Tradução de Ivo Storniolo e Euclides Martins Balancin. São Paulo: Paulus, 1990. p. 1280-1350.

MATEUS. In: Bíblia sagrada. Tradução de Ivo Storniolo e Euclides Martins Balancin. São Paulo: Paulus, 1990. p. 1238-1279.

MONDONI, Danilo. O cristianismo na antiguidade. São Paulo: Loyola, 2014. 200 p.

NUNES, Maria José Rosado. O impacto do feminismo sobre o estudo das religiões. Cadernos Pagu, Campinas, n. 16, p. 79-96, 2001.

NUNES, Maria José Rosado. Direitos, cidadania das mulheres e religião. Tempo social, São Paulo, v. 20, n. 2, nov. 2008.

RICOEUR, Paul. A hermenêutica bíblica. Tradução de Paulo Meneses. São Paulo: Loyola, 2006. 328 p.

ROMANOS. In: Bíblia sagrada. Tradução de Ivo Storniolo e Euclides Martins Balancin. São Paulo: Paulus, 1990. p. 1440-1459.

ZABATIERO, Julio Paulo Tavares; LEONEL, João. Bíblia, literatura $e$ linguagem. São Paulo: Paulus, 2011.

TIMÓTEO, 1. In: Bíblia sagrada. Tradução de Ivo Storniolo e Euclides Martins Balancin. São Paulo: Paulus, 1990. p. 1529-1534. 